\title{
ART
}

\section{ЕВОЛЮЦІЯ СВІТЛА У ЖИВОПИСІ ОЛЕКСАНДРА МУРАШКА}

\author{
Мосендз Оксана Олегівна, \\ аспірантка Харківської Державної Академії Дизайну та Мистечтв, викладач кафедри \\ мистецтвознавства Київського Національного Університету Культури і Мистецтв, \\ Дніпровський факультет
}

DOI: https://doi.org/10.31435/rsglobal_ijitss/30122019/6852

\section{ARTICLE INFO}

Received 10 October 2019 Accepted 17 December 2019

Published 30 December 2019

\section{KEYWORDS}

artist, creativity, sunlight, color, artistic image, realism, impressionism, modern.

\begin{abstract}
The aim of the work is to identify evolution in search of ways to transmit light in the work of Alexander Murashko. Considering the artist's work from the first studies to the last masterpieces, one can observe the difficult creative path of the master. Soft, diffused light in the first works, still bearing the imprint of icon-painted canons of lighting. Realism in the transmission of lighting in paintings created under the guidance of I. Repin. The play of light and reflexes, the radiance of night lights, the transmission of light-air space - these are the discoveries of the Impressionists, who replenished the artist's palette. Decorativeism, sculpting forms with the help of light - these helped Murashko to nourish Modern. Having absorbed all these components into his work, synthesizing them, enriching them with Ukrainian folk color, A. Murashko created his own unique style, piercing the canvas with the radiance of sunlight.
\end{abstract}

Citation: Мосендз Оксана Олегівна. (2019) Evoliutsiia Svitla u Zhyvopysi Oleksandra Murashka. International Journal of Innovative Technologies in Social Science. 9(21). doi: 10.31435/rsglobal_ijitss/30122019/6852

Copyright: (C) 2019 Мосендз Оксана Олегівна. This is an open-access article distributed under the terms of the Creative Commons Attribution License (CC BY). The use, distribution or reproduction in other forums is permitted, provided the original author(s) or licensor are credited and that the original publication in this journal is cited, in accordance with accepted academic practice. No use, distribution or reproduction is permitted which does not comply with these terms.

Олександр Мурашко один з найяскравіших українських художників кінця XIX початку $\mathrm{XX}$ століття. Як і багато художників цього часу, О. Мурашко перебував у постійному творчому пошуку. Маючи академічну художню освіту, вбираючи новітні західноєвропейські тенденції: імпресіонізм, символізм, модерн, він знайшов свій власний художній стиль. Одним з основних напрямків пошуків Олександра Мурашка була проблема передачі на полотні сонячного світла. Практично в усіх картинах Олександра Мурашка світло відіграє одну з головних ролей для створення художнього образу. «Трудно найти художника, а тем более портретиста, в творчестве которого солнечный свет занимал бы такое значительное место» - зауважує мистецтвознавець Н. Асєєва у своїй монографії [2, с. 137].

Багато видатних мистецтвознавців присвятили свої роботи вивченню творчості О. Мурашка - це Д. Антонович, Г. Лукомський, Л. Членова, Н.Асєєва, А. Шпаков, А. Жаборюк, О. Жбанкова, I. Павельчук та інші. Д. Антонович у 1925 р. писав: «Мурашко ніколи у своїй творчості не спинявся, одні впливи він переживав, користуючись другими, а сам в дійсності простував назустріч тому мистецькому зворотові, який дає себе відчути в малярстві Європи вже після його смерті» [1, с. 13]. У даній роботі ми простежуємо еволюційний шлях, який пройшов майстер у своїй творчості, в пошуках способів передачі на полотні світла.

3 дитинства А. Мурашко був оточений іконами. Його вітчим був власником іконописної майстерні й бажав передати свою справу пасинку, тому перші, нехай і ремісничі, проте художні навички, О. Мурашко отримав у майстерні у Чернігові. Згодом, іконописець зі своєю 
майстернею переїжджає до Києва, де у той час зводили й оздоблювали Володимирський собор, на роботи в якому він отримав підряд. Незабутній слід залишили в душі юного Сашка враження від робіт великих майстрів В. Васнецова, М. Нестерова, М. Врубеля. Зіткнувшись $з$ великими художниками, занурившись у творчу атмосферу, працюючи над копіями розписів Володимирського собору, він загорівся бажанням стати справжнім митцем. Не отримавши схвалення вітчима, Олександр крадькома відвідував заняття в художній школі свого дядька Миколи Івановича Мурашка. Написані у той час перші етюди наповнює м'якість світла, поки що стриманого. Це можна пов'язати 3 традиціями українського іконопису, котрий зберіг принципи візантійської символіки світла: в іконі не застосовувалася гра світла і тіні: воно рівномірно стелилося площинами.

У формуванні юного художника, поряд 3 В. Васнецовим, відіграв важливу роль А. Прахов, який умовив вітчима Мурашка відпустити Олександра на навчання у Петербурзькій Академії мистецтв. Навчання у майстерні I. Рєпіна залишило значний слід у творчості Мурашка. Вміння гармонійно включити в образне рішення картини світло, використовувати тональність кольору, насиченість і світлоту є сильною стороною творчості Мурашка, і в цьому йому допоміг набутий досвід навчання у цій майстерні.

Перша значна картина Мурашка - дипломна робота «Похорон кошового» 1900 р., за яку він одержав право на пенсіонерську поїздку за кордон, без сумніву, написана під впливом I. Рєпіна. Драматизм сюжету підкреслюється ритмічною композицією, спрямованістю руху похоронної процесії безпосередньо на глядача, відчуттям гучного тупоту сотні ніг, акцентуванням уваги на суворих обличчях. Але, не лише композицією, але й «усіма живописними засобами, складним освітленням, насиченою колірною гамою темних тонів художник створює настрій трагічної сцени. Похмурі й глухі барви нічного пейзажу додають відчуття тривоги. Тріпотить тремтяче полум'я свічок в руках запорожців, освітлюючи їх скорботні обличчя. Гра світлових відблисків у присмерках, призахідна заграва посилюють напругу композиції» підкреслює видатна дослідниця творчості Мурашка Л. Членова [7, с. 57].

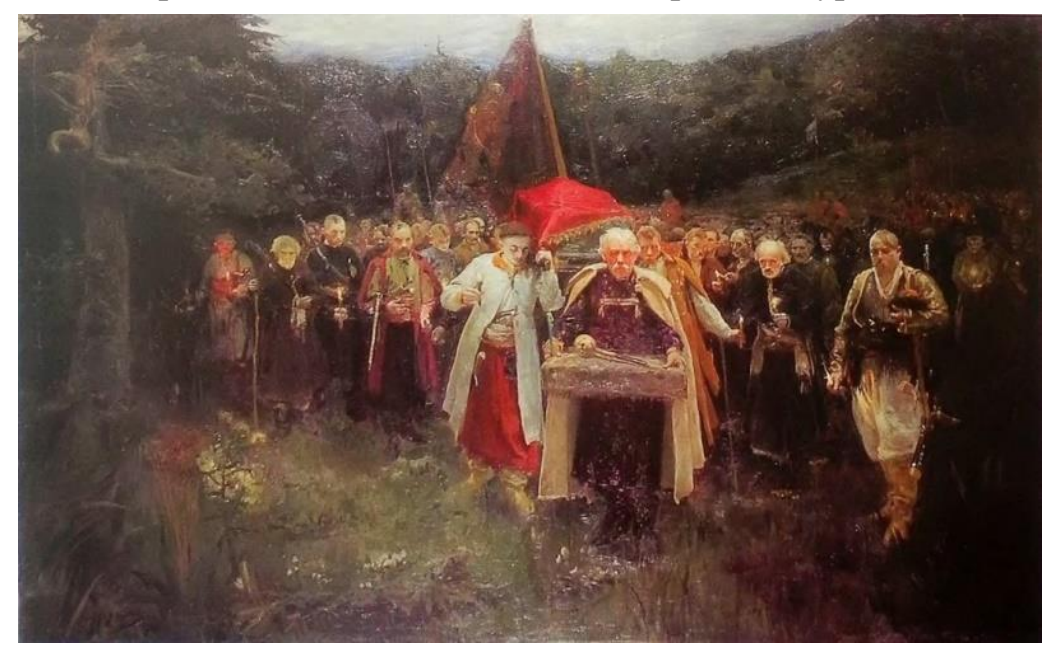

Рис.1. «Похорон кошового» 1900 p.

Отримавши за картину «Похорон кошового» звання вільного художника і право на закордонне відрядження як пенсіонер Академії мистецтв, Мурашко подорожує країнами Європи, наповнюючись враженнями, працюючи та продовжуючи вчитися живопису. Прибувши у Париж прихильником реалістичних традицій, стриманого світла і кольору, під впливом революційних пошуків імпресіонізму, Мурашко змінив монохромність колориту на витонченість відтінків кольору, гру світла і рефлексів, розмаїття тональних переходів. Передача освітлення осяйного електричними вогнями нічного міста захоплює Мурашка. Він ставить перед собою нове завдання: навчитися передавати атмосферу нічного міста, тремтливо блискучого вогнями, наповненого світловими рефлексами. Зміни, що відбулися у творчості митця можна прослідкувати й в картинах «На вулицях Парижа» 1903 р., «Біля кав’ярні» 1903 р. 


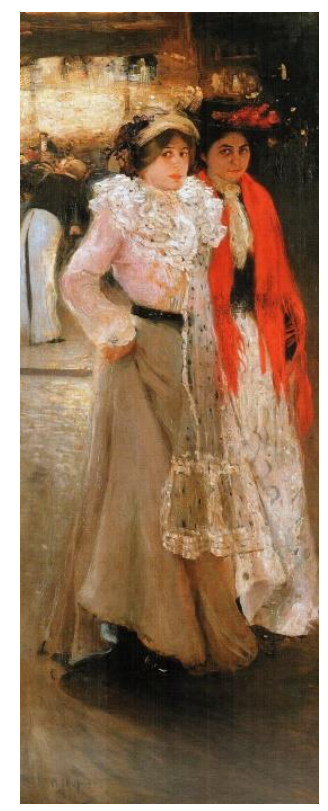

Рис.2. «Біля кав:ярні», 1903 p.

Знайомство 3 мистецтвом Європи Мурашко продовжив у Мюнхені. Відвідуючи приватні художні майстерні, Мурашко відкрив для себе європейський модерн, в якому, на відміну від французького імпресіонізму, митці наповнюючи картини світло-повітряною грою і динамічними переливами градацій кольору, зберігали форму і структуру предметів. Художнику імпонує мюнхенський сецесіон, якому притаманна особлива декоративно-узагальнена манера живопису, коли світло і рефлекси, переломлюючись «на гранях» форми, не порушують ії чіткої побудови. Нові мюнхенські художники, на противагу французьким імпресіоністам, намагались поєднати імпресіоністичну манеру письма 3 чітким рисунком та узагальненим ліпленням пластично великих форм предметів і людини [8, с.16]. Поєднання імпресіоністичного наповнення повітрям і грою сонця з модерністською декоративністю яскравих кольорових плям можна спостерігати в картині О. Мурашка «Карусель» 1906 р., яка справила велике враження на мистецьку громадськість Мюнхена і отримала золоту медаль на X міжнародній виставці у Мюнхені. Лише кілька років відокремлюють картину «Карусель» від паризьких пошуків митця. Але які великі зміни ми бачимо! Це стосується і композиції, і колориту, і теми, яка для Мурашко вже не чужа, не поверхова, а йде з самої глибини його душі. Радісне сонячне сяйво грає на квітучих обличчях сільських дівчат, мяльовничи пістряві барви, пронизані веселими променями сонця, створюють настрій святковості. Як зауважує Л. Корж-Радько, «живописна манера Олександра Мурашка завжди мала дивовижне українське забарвлення, виразний український підтекст» [4, с. 132] 3 цієї пори, народна тема буде наповнювати його творчість глибиною, стане джерелом яскравих вражень і відкриттів.

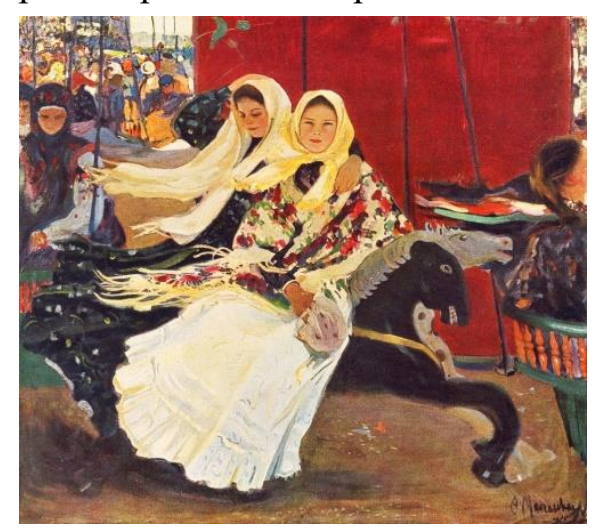

Рис.3. «Карусель» 1906 p.

У творчості Мурашка, після перебування в Мюнхені, спостерігається низка змін, і найзначніші відбулися у характері освітлення в його полотнах. У щоденнику Миколи Івановича 
Мурашка, який перший помітив його зацікавлення грою сонця і дуже уважно стежив за розквітом творчості свого талановитого племінника, згадується «гонитва за силою сонця, за плямками».

Повернувшись в Україну, Мурашко застосував отриманий досвід імпресіонізму і модерну для створення свого художнього стилю, живописної системи, шляхом ліплення цілісної форми у сяйві найтонших градацій сонячного світла. У картині «На кормі. Портрет Жоржа Мурашка» 1906 р., художник із сонячних плям конструює орнамент, і пластичні контури постаті Жоржа сприймаються як декоративний візерунок, що було зазначено I. Павельчуком [5, с. 46].

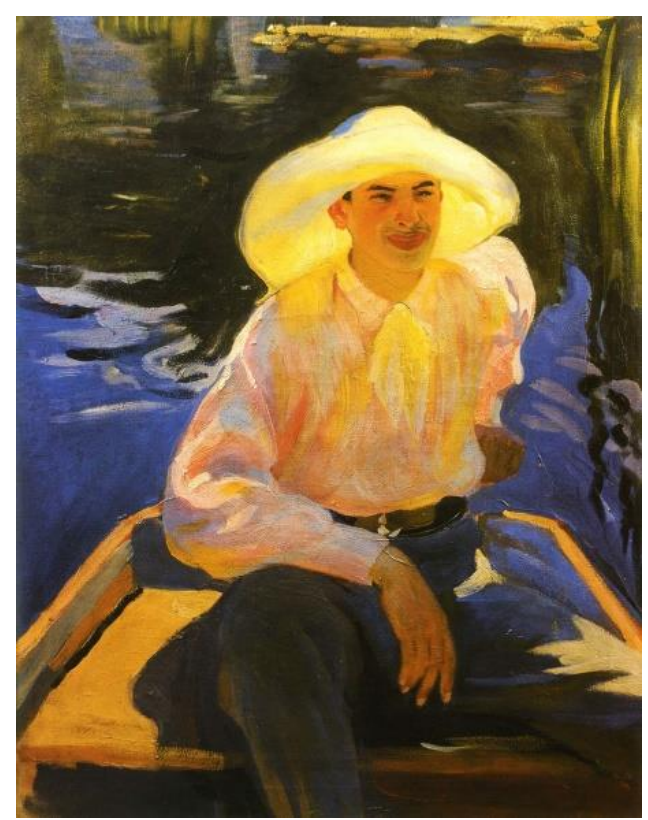

Рис.4. «На кормі. Портрет Жоржа Мурашка» 1906 р.

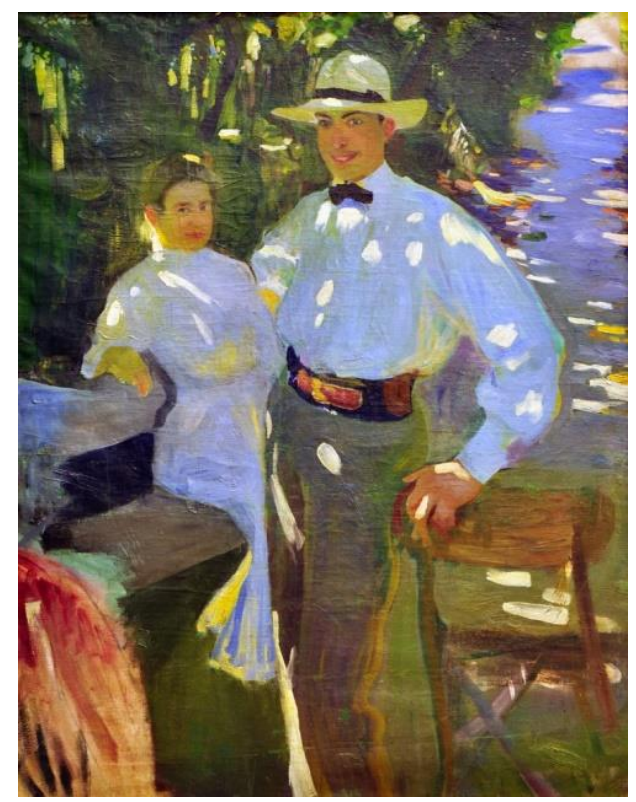

Рис.5. «Сонячні плями. Портрет Жоржа Мурашка» 1908 р.

У картині «Благовіщення» 1909 р., у своїй єдиній картині на біблійну тему, Мурашко розміщує ангела на золотому фоні. Знаючи тонкощі іконописної символіки, художник використовує сліпуче сонячно сяйво як символ небесного царства. Саме це сяюче світло i створює ефект присутності «іншого світу», звідки приходить посланець, в цьому ми згодні $з$ О. Сівковим [6, с.13]. 


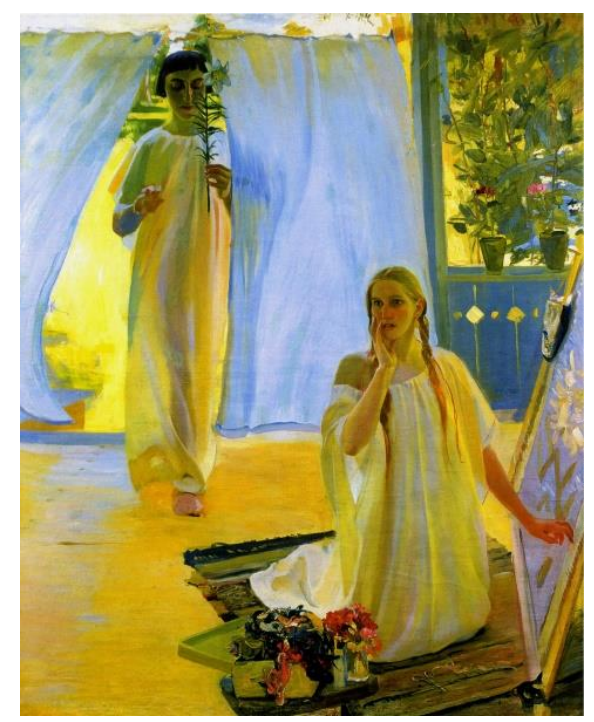

Рис.6. «Благовіщчення» 1909 р.

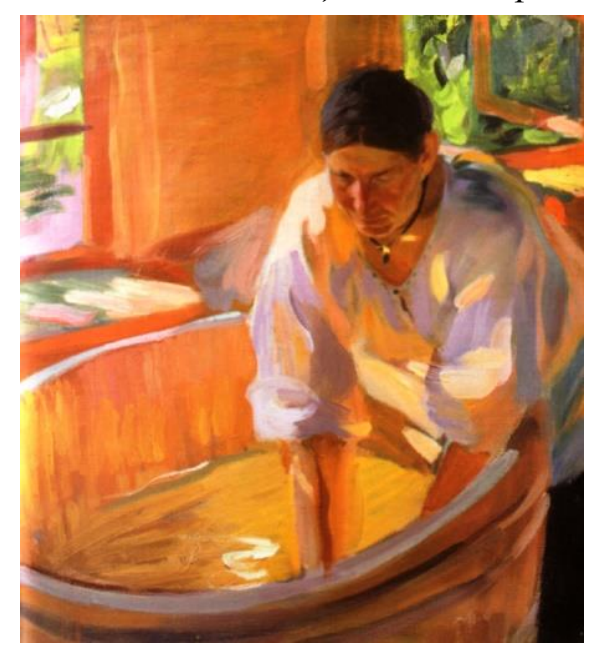

Рис.7. «Праля» 1914 p.

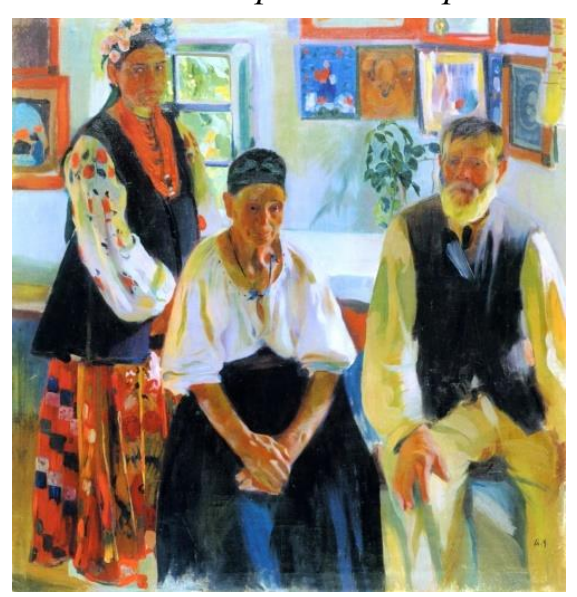

Рис.8. «Селянська родина» 1914 р.

Від картини до картини сила сонячного світла все більше наростає, від сонячних плям до потужного потоку, котрий розливається з такою силою, що, дивлячись на нього, починаєш мружитися! В останніх творах «Жінка 3 настурціями» 1918 р. і «Продавщиці квітів» 1917 р. О. Мурашко ліпить форму одним лише кольором, відмовляючись від традиційного засобу світлотіні. Завдяки колірним контрастам художник підсилює звучання фарб, і ніби переводить світло в його кольоровий еквівалент, створюючи яскравий та гармонійно-пластичний образ світу, що було зазначено О. Жбанковою [3, с. 18] 


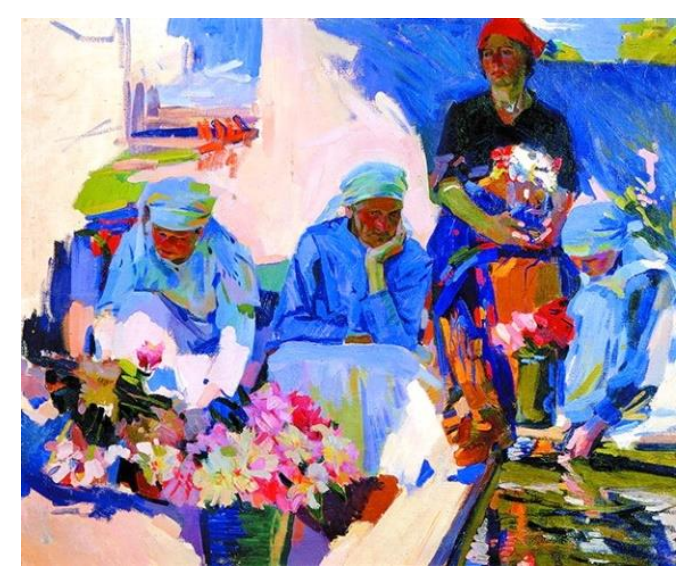

Рис.9. «Продавщиці квітів» 1917 p.

Отже, підсумовуючи, згадаємо думку видатної дослідниці творчості О. Мурашка Л. Членової: «Головною для художника залишалася проблема відтворення світла, яке вносило гармонію в його композиції. За допомогою світла, його найтонших модуляцій і створював Мурашко свої колористичні шедеври» [7, с.136].

Висновки. За результатами проведеного дослідження творчості О. Мурашка, з'ясовано еволюційний шлях вдосконалення його майстерності передачі на полотні світла. Пройшовши через складні періоди пошуків та самовдосконалення, увібравши у свою творчість різноманітні художні напрямки, синтезувавши їх, збагативши народним українським колоритом, Олександр Мурашко, якого по праву називають «художником світла», створив свій власний неповторний стиль передачі на полотні світла.

\section{ЛІТЕРАТУРА}

1. Антонович Д. Олександер Мурашко. Серія: Майстри українського мистецтва - Прага, Видавництво української молоді, 1925. - 14c.

2. Асеева Н. Украинское искусство и европейские художественные центры (конец XIX- начало XX века). - К: Наукова думка, 1989. - 198с.

3. Жбанкова О. Імпресіонізм. Українські враження. - Музейний провулок, 2009, №3, (c. 10-21)

4. Корж-Радько Л.А. Компаративний аналіз портретного живопису в українському мистецтві кінця XIX - початку XX ст. - Дизайн освіта в Україні: перспективи розвитку, 2013 №3 (с. 130-134)

5. Павельчук I. Імпровізації імпресіонізму в практиці Олександра Мурашка: синтез об'єктивної емпіричної дійсності та суб'єктивних вражень як підготовка до художнього узагальнення натури. Вісник Львівської національної академії мистецтв. Вип.36/2018 - (с. 40-50)

6. Сівков О. Символізм і модернізм у малярстві Олександра Мурашка. - Образотворче мистецтво, 2001 №2, (c. 12-16).

7. Членова Л. Олександр Мурашко. Сторінки життя і творчості. - Хм: Галерея, К: Артанія Нова, 2005. - 256c.

8. Шпаков А. Олександр Олександрович Мурашко. Нарис про життя і творчість. - К: Державне видавництво образотворчого мистецтва і музикальної літератури УРСР, 1959. - 28c. 